much sound judgment behind them that they were in most cases incontrovertible, and the very forcefulness with which he expressed himself removed any sting from his words. His mental activity and strength of character would indubitably have won for him a high place in the King's Service had he been spared, and his death removes a personality which cannot be replaced.

C.G.G.

\title{
ALFRED ARKELL HARDWICK
}

Alfred Arkell Hardwick was born in the year 1878 in London, and his career throughout was of a most romantic description. At the age of some fourteen years he went as an apprentice to sea, and sailed several voyages from this country to Australia, South Africa, and Japan-serving altogether three years. On one occasion when rounding Cape Horn he was washed overboard, and was only soved by the returning wave carrying him back on deck again. When he was between seventeen and eighteen he landed in South Africa and there-disappointed in a venture he had undertaken with a friendjoined the Mashonaland Police, serving through the Mashonaland campaign. He gained a medal and bar for this-being mentioned in dispatches. Shortly afterwards we find him in Egypt, where he was employed on the Nile Irrigation Works. There meeting a friend, Mr. George West, he later accompanied him south when the Boer War broke out. The next two or three years find him big-game hunting and exploring in Central Africa, and on his return to England he wrote a book detailing his experiences, entitled: "An Ivory Trader in North Kenia," published by Longmans, Green \& Company. As a result of the experience gained he started a Nigerian Trading Company, and went out to West Africa for "The African World" as a special commissioner. Returning from there he went to Morocco with a small party of journalists accompanying Mr. Laurence Harris, of "The Graphic." On his return from Morocco he went to America and was connected with Dr. Spratt, of Coatsville. After a year or so out in the States, Hardwick returned to England and joined Handley Page, Limited, and was with them as Assistant Manager from the early part of 1911 until his death.

Of genial personality, Hardwick had a winning manner that made great friends wherever he went-their circle is world-wide. His keenness for aviation knew no bounds, and he made his work his hobby in every sense of the word. To those who had the pleasure of working with him and of knowing his cheery personality-always helping, always seeking to improve-the loss is indeed a great one. His unfailing belief in the immense future of aviation was such that if he had felt that the sacrifice of his life would in any way have aided the final accomplishment of the mastery of the air, he would willingly have laid it down for so high a purpose.

F.H.P.

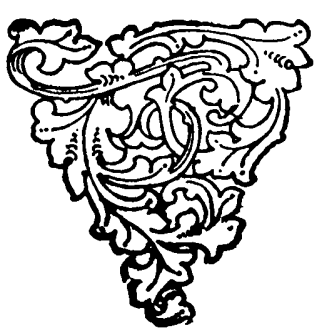

